\title{
PPA OR OECM? DIFFERENTIATING BETWEEN
PRIVATELY PROTECTED AREAS AND OTHER
EFFECTIVE AREA-BASED CONSERVATION
MEASURES ON PRIVATE LAND
}

Brent A. Mitchell ${ }^{1^{*}}$, James A. Fitzsimons ${ }^{2,3}$, Candice M.D. Stevens ${ }^{4}$, Dale R. Wright ${ }^{5}$

*Corresponding author: brentmitchell@qlf.org

${ }^{1}$ Quebec Labrador Foundation / Atlantic Center for the Environment, Ipswich, MA, USA

${ }^{2}$ The Nature Conservancy, Carlton, VIC, Australia

${ }^{3}$ School of Life and Environmental Sciences, Deakin University, Burwood, VIC, Australia

${ }^{4}$ BirdLife South Africa, Dunkeld West, Johannesburg, South Africa

${ }^{5}$ BirdLife South Africa, Cape Town, South Africa

\section{ABSTRACT}

Private land conservation has an increasingly important role in ensuring global conservation networks are comprehensive, adequate and representative. To contribute to the Convention on Biological Diversity's Aichi Target 11, areas on private land must be either privately protected areas (PPAs) or 'other effective area-based conservation measures' (OECMs) on private land. Here we compare PPAs to OECMs on private land, clarify misconceptions and provide case studies for how two jurisdictions, Australia and South Africa, have worked through applying these categories to local private land conservation mechanisms.

Key words: privately protected area, protected area, OECM, private land conservation, security

\section{INTRODUCTION}

Protected areas, as one of the cornerstones of conservation efforts, have been the subject of significant policy work and considered definition (e.g. Dudley, 2008), despite the differing legal, social and policy approaches to these mechanisms by jurisdictions around the world. Privately protected areas (PPAs), while being applied and recognised by a number of jurisdictions for well over two decades (Mitchell, 2005; Fitzsimons, 2015), have had increased focus at an IUCN policy level in the past five years (e.g. Stolton et al., 2014; Bingham et al., 2017) and have grown in profile as a significant mechanism to help achieve global conservation targets.

Here we compare PPAs to 'other effective area-based conservation measures' (OECMs) on private land, clarify misconceptions and provide case studies for how two jurisdictions, Australia and South Africa, have worked through applying these categories to local private land conservation mechanisms.

\section{Distinguishing OECMs from PPAs: Why it matters}

To contribute to the Convention on Biological Diversity's (CBD) Aichi Target 11, areas on private land must be either privately protected areas (PPAs) or 'other effective area-based conservation measures' on private land. Currently both protected areas and OECMs are listed as qualifying equally towards the numerical targets to be achieved by the year 2020. However, discussion on new targets for the CBD post-2020 have begun, and it is likely that protected areas and OECMs will be considered separately going forward.

Perhaps more significantly, future assessments of the effectiveness of various conservation mechanisms will depend on a clear understanding of the differences among categories and types of protected and conserved areas. IUCN is establishing the definitional framework upon which comparative analyses of these mechanisms will depend. In considering private governance, it is 
important that analysts and other authorities are able to distinguish between PPAs and OECMs on private land.

\section{What is a privately protected area?}

IUCN defines a protected area as a clearly defined geographical space, recognised, dedicated and managed, through legal or other effective means, to achieve the long-term conservation of nature with associated ecosystem services and cultural values (Dudley, 2008).

A privately protected area (PPA) is a protected area, as defined above, under private governance including by:

- individuals and groups of individuals;

- non-governmental organisations (NGOs);

- corporations - both existing commercial companies and sometimes corporations set up by groups of private owners to manage groups of PPAs;

- for-profit owners;

- research entities (e.g. universities, field stations); or

- religious entities (Stolton et al., 2014).

The 2016 IUCN World Conservation Congress (WCC) approved a resolution on supporting PPAs (WCC-2016Res-036). This resolution acknowledged the "valuable work and the report of the Futures of Privately Protected Areas project [Stolton et al. 2014] and its proposed concept of privately protected area". Through the resolution, IUCN members recognise the complementarity of PPAs to other governance types, and their ability to contribute to connectivity within the broader conservation estate. Similarly, UNEP/CBD/ COP/DEC/XII/ 1917 October 2014 "Recognizes the contribution of private protected areas, in addition to public and Indigenous and local community conserved areas, in the conservation of biodiversity, and encourages the private sector to continue its efforts to protect and sustainably manage ecosystems for the conservation of biodiversity".

\section{What is an 'other effective area-based conservation measure'?}

An OECM, as referenced in Aichi Biodiversity Target 11, is defined in the draft Guidelines for Recognising and Reporting Other Effective Area-based Conservation Measures (IUCN WCPA, 2018) as: A geographically defined space, not recognised as a protected area, which is governed and managed over the long-term in ways that deliver the effective in-situ conservation of biodiversity, with associated ecosystem services and cultural and spiritual values.
The draft OECM Guidelines suggest "The distinguishing criterion is that protected areas should have a primary conservation objective, whereas an OECM should deliver the effective in-situ conservation of biodiversity, regardless of its objectives".

\section{Some early confusions among definitions}

Earlier versions of the OECM Guidelines contained some confusing and contradictory explanations on the relationship between PPAs and OECMs. While this has been corrected in the latest draft of the OECM Guidelines, it is important to clarify these issues here to reduce doubt for policy makers and practitioners. The Futures of Privately Protected Areas report (Stolton et al., 2014) and subsequent published guidance from the WCPA Specialist Group on Privately Protected Areas and Nature Stewardship (Bingham et al., 2017) made it very clear that PPAs are areas that fit the IUCN protected area definition. Earlier drafts of the OECM guidance suggested that PPAs can fit either the IUCN protected area definition or the OECM definition, dependent solely on whether the area is recognised by the government or not. Indeed the draft OECM Guidelines previously stated that an OECM can be a PPA that is not reported by the government, or a protected area whose custodians do not want it to be reported as a protected area. This is not correct. An area cannot both be an OECM and a protected area; if it meets the IUCN definition, it is a protected area. While there are acknowledged issues with reporting of PPAs to national databases and the World Database on Protected Areas (WDPA) (Bingham et al., 2017), this does not impact on the classification of an area. That is, an area can be classified as a PPA even if it is not reported as such to the WDPA. On the other hand, it should be stated that simply calling a place a PPA does not make it so. Management must reflect the definition.

\section{Practically determining differences}

While a variety of legal mechanisms are available in many jurisdictions for creating both PPAs and OECMs, a full description of these tools is beyond the scope of this paper (see Bowles et al., 1998). Furthermore, the legal tool (or financial mechanism) used may not have a bearing on whether an area should be considered a PPA and not an OECM, or vice versa. Indeed, the fact that an area is under private governance is also not a determinant as to whether it should be counted as PPA or OECM.

What is significant in making such a determination is whether the site in question meets the IUCN definition of a protected area (Figure 1). Again, we emphasise that 
no area can simultaneously be a PPA and an OECM. As outlined above, the first filter to apply when determining whether a place is a PPA or OECM is whether it meets all the criteria to be considered a protected area. Only then should the governance be considered. A private area that meets the protected area definition is a PPA; otherwise, if it does not meet the protected area definition it may be a private OECM.

\section{CASE STUDIES}

Some jurisdictions have already determined the types of private land conservation agreements that would qualify as a PPA and OECM on private land categories. Here we provide case studies for this distinction as it has been applied in Australia and South Africa. We are aware that other countries have also initiated this line of work.

\section{Australia}

In Australia, the objective of building a national reserve system that includes protected areas of public, private and Indigenous governance types has been embedded
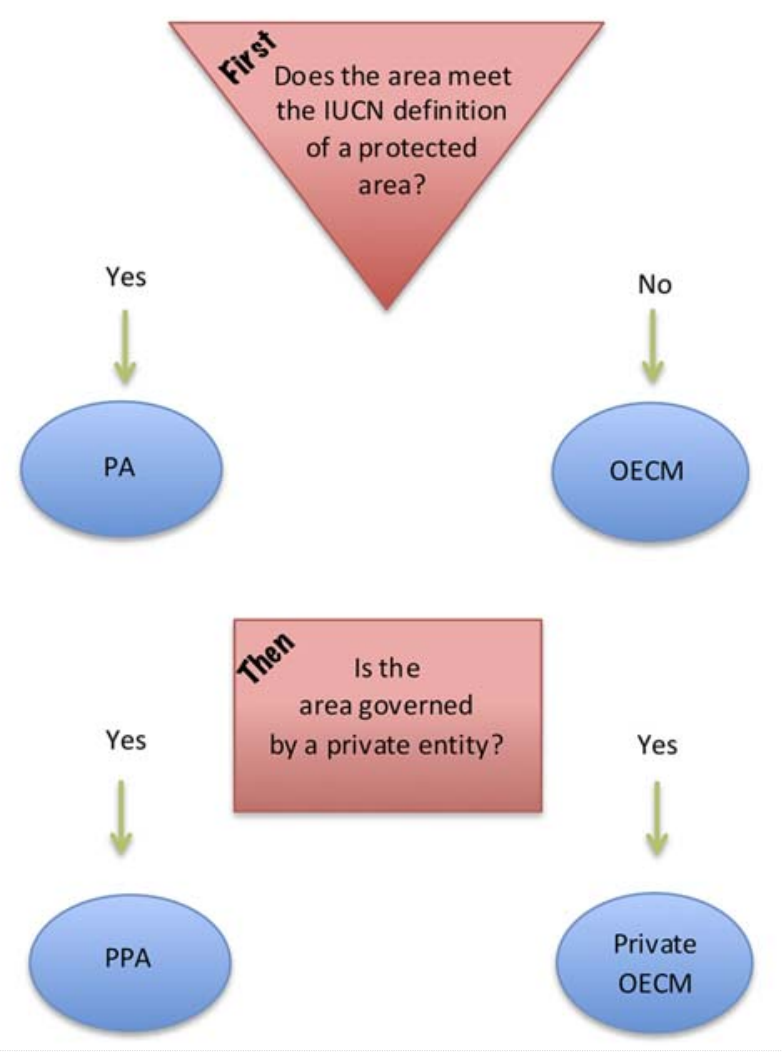

Figure 1. Flow chart to practically determine differences between privately protected areas and OECMs on private land in policy for over 25 years and has been actively pursued in that time (e.g. Taylor et al., 2014). The only nationally agreed definition of a PPA is that developed by the Natural Resource Management Ministerial Council (NRMMC) for Australia's Strategy for the National Reserve System 2009-2030 (NRMMC, 2009). The NRMMC, which consisted of the Australian Commonwealth, state, territory and New Zealand government ministers responsible for primary industries, natural resources, environment and water policy, stated "A fundamental requirement of any area's eligibility for inclusion within the National Reserve System is that it must meet the IUCN definition of a 'protected area' (Dudley, 2008)" (NRMMC, 2009, p. 42). The Natural Resource Management Ministerial Council defined further 'Standards for inclusion in the National Reserve System' with three standards applying generally across all tenure types and a fourth (dealing with security) specific to different tenures (i.e. public, private, Indigenous) The NRMMC provides further definition of the term legal or other effective means' for the purposes of inclusion in the National Reserve System:

1. Legal means: Land is brought under control of an Act of Parliament, specialising in land conservation practices, and requires a parliamentary process to extinguish the protected area or excise portions from it.

2. Other effective means: for contract, covenant, agreements or other legal instrument, the clauses must include provisions to cover:

- long-term management - ideally this should be in perpetuity but, if this not possible, then the minimum should be at least 99 years;

- the agreement to remain in place unless both parties agree to its termination;

- a process to revoke the protected area or excise portions from it is defined; for National Reserve System areas created through contribution of public funding, this process should involve public input when practicable;

- the intent of the contract should, where applicable, be further reinforced through a perpetual covenant on the title of the land; and

- 'well-tested' legal or other means, including nongazetted means, such as through recognised traditional rules under which Indigenous Protected Areas (community conserved areas) operate or the policies of established non-government organisations (NRMMC, 2009, p. 43). 
For the purposes of determining which private land conservation mechanisms would qualify as PPAs and thus inclusion in the National Reserve System, an assessment was conducted in the state of Victoria (Table 1) (Fitzsimons, 2006). The determination of protected area status for private land conservation mechanisms largely involves an assessment of the strength of the legislation and/or legal agreements which protect that land (security); the length of time those agreements are in place (permanence); and management intent and obligations to manage the land. The emphasis each mechanism places on these varies within and between Australian jurisdictions.

\section{Security}

Security denotes the relative strength of the protection agreement in place, specifically, the level of authority that can sign and revoke/dissolve an agreement. The level of authority reflects a level of transparency and accountability in decision-making. In its definition of private land conservation agreements that would qualify as protected areas, the WCPA ANZR (2000) identifies two differing levels of authority:

- Section 3.1.2 (Inclusion Guideline ii): an area subject to protective covenant on title or agreement under the provisions of land titles legislation or wildlife conservation legislation. The covenant and land uses allowed should be subject to alteration only by a Minister of Parliament, in consultation with the Minister administering environmental planning, conservation or wildlife issues for that State; and

- Section 3.2.5 (Inclusion Guideline ii): freehold, Crown and leasehold land subject to protective covenant on title or agreement under the provisions of land titles legislation or wildlife conservation legislation, where the covenant and land uses allowed are subject to alteration only by a Minister (or Director), in consultation with the Minister (or Director) administering environmental planning or conservation and wildlife issues for that State.

\section{Permanence}

Ideally, for private conservation agreements to qualify as protected areas they would be binding on the title of that land and carry over to future owners in perpetuity. However, a 99-year agreement was specified as a minimum time for qualification by the NRMMC (2005).

Management intent and obligations

The primary management aim for protected areas is biodiversity conservation. Therefore, a statement of intent to manage the land in question for biodiversity or other natural features is required in the agreement. It is important to distinguish between the intent to proactively manage for biodiversity conservation, and restrictions on particular uses which may impact negatively on biodiversity (e.g. an environmental significance overlay in a local government planning scheme).

\section{Determining PPAs nationally}

In a review of PPAs across Australia, Fitzsimons (2015) showed that conservation covenanting programmes (Figure 2), land purchased by non-government organisations through the Australian Government's National Reserve System Program (Figure 3) and less frequently, areas protected by special legislation or under state/territory national parks legislation, are the main 'types' of PPAs in that country. In September 2013, there were approximately 5,000 terrestrial properties that could be considered private protected areas in Australia covering 8,913,000 ha (Fitzsimons, 2015).

However, not all conservation covenanting programmes would necessarily qualify as PPAs due to either the primary purpose or the level of authority identified in

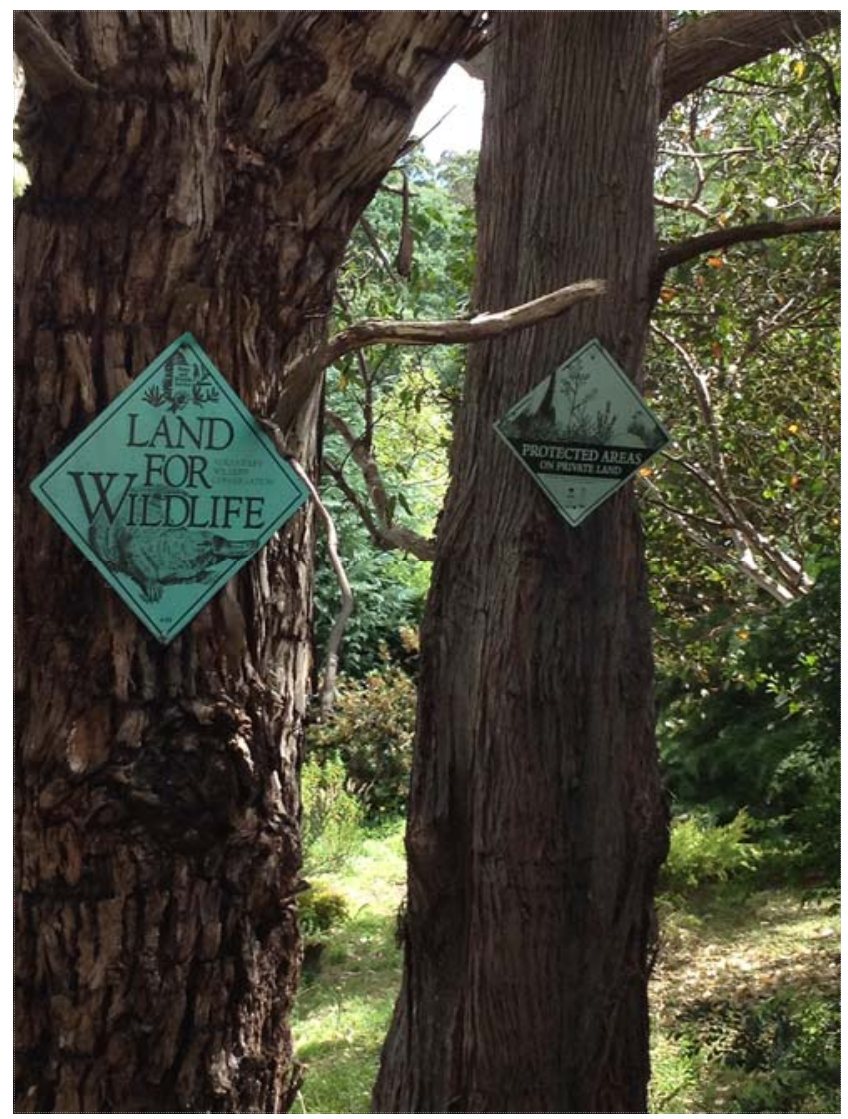

Figure 2. A conservation covenant in Tasmania, Australia: a property managed for the primary purpose of conservation with a secure agreement which runs with the title of the land and thus a privately protected area (C) James Fitzsimons 
Table 1. Checklist of criteria for assessing protected area status of private land conservation mechanisms in Victoria, Australia (from Fitzsimons, 2006)

\begin{tabular}{|c|c|c|c|c|c|c|}
\hline \multicolumn{2}{|c|}{ Agreement/property type } & Act & Security & Permanence & $\begin{array}{l}\text { Management } \\
\text { intent }\end{array}$ & $\begin{array}{l}\text { Protected area } \\
\text { status }\end{array}$ \\
\hline \multirow{4}{*}{$\begin{array}{l}\text { Trust for } \\
\text { Nature }\end{array}$} & $\begin{array}{l}\text { Conservation } \\
\text { Covenants }\end{array}$ & VCTA & Y & Y & Y & Yes \\
\hline & Reserves (NRSP) & VCTA & Y & Y & Y & Yes \\
\hline & Reserves (Non-NRSP) & VCTA & $x$ & $x$ & Y & No \\
\hline & Revolving fund & VCTA & $\mathrm{Y}^{*}$ & $\mathrm{Y}^{*}$ & Y & No* \\
\hline \multicolumn{2}{|c|}{ NRSP Private Protected Areas } & N/A & Y & Y & Y & Yes \\
\hline \multicolumn{2}{|c|}{$\begin{array}{l}\text { Land Management Cooperative } \\
\text { Agreements }\end{array}$} & CFLA & $x$ & $\begin{array}{l}\text { Depends on } \\
\text { terms }\end{array}$ & $\begin{array}{l}\text { Depends on } \\
\text { terms }\end{array}$ & No \\
\hline \multicolumn{2}{|c|}{$\begin{array}{l}\text { Wildlife Management Cooperative } \\
\text { Areas }\end{array}$} & WA & Y & $\begin{array}{l}\text { Depends on } \\
\text { terms }\end{array}$ & $\begin{array}{l}\text { Depends on } \\
\text { terms }\end{array}$ & $\begin{array}{c}\text { Depends on terms of } \\
\text { agreement }\end{array}$ \\
\hline \multicolumn{2}{|c|}{ Wildlife Sanctuaries } & WA & Y & $x$ & $x$ & No \\
\hline \multicolumn{2}{|c|}{ Section 173 Agreements } & PEA & $x$ & $\begin{array}{l}\text { Depends on } \\
\text { terms }\end{array}$ & $x$ & No \\
\hline \multicolumn{2}{|c|}{$\begin{array}{l}\text { BushTender ( } \& \text { similar } \\
\text { agreements) - permanent (VCT) }\end{array}$} & VCTA & Y & Y & Y & Yes \\
\hline \multicolumn{2}{|c|}{$\begin{array}{l}\text { BushTender ( } \& \text { similar } \\
\text { agreements) - permanent (CFL) }\end{array}$} & CFLA & $x$ & $\begin{array}{l}\text { Depends on } \\
\text { terms }\end{array}$ & $\begin{array}{l}\text { Depends on } \\
\text { terms }\end{array}$ & No \\
\hline \multicolumn{2}{|c|}{$\begin{array}{l}\text { BushTender ( } \& \text { similar } \\
\text { agreements) - fixed term }\end{array}$} & N/A & $x$ & $x$ & Y & No \\
\hline \multicolumn{2}{|c|}{$\begin{array}{l}\text { Public Authority Management } \\
\text { Agreement }\end{array}$} & FFGA & $x$ & $\begin{array}{l}\text { Depends on } \\
\text { terms }\end{array}$ & Y & No \\
\hline \multicolumn{2}{|c|}{ Interim Conservation Orders } & FFGA & $x$ & $x$ & $\begin{array}{l}\text { Depends on } \\
\text { terms }\end{array}$ & No \\
\hline \multicolumn{2}{|c|}{ EPBC Conservation Agreements } & EPBCA & $\mathrm{Y}$ & $\begin{array}{l}\text { Depends on } \\
\text { terms }\end{array}$ & $\begin{array}{l}\text { Depends on } \\
\text { terms }\end{array}$ & $\begin{array}{c}\text { Depends on terms of } \\
\text { agreement }\end{array}$ \\
\hline \multicolumn{2}{|c|}{ Critical Habitat } & EPBCA & Y & ? & $x$ & No \\
\hline \multicolumn{2}{|c|}{ Indigenous Protected Areas } & N/A & Y & Y & Y & Yes \\
\hline \multicolumn{2}{|c|}{ Land for Wildlife properties } & N/A & $x$ & $x$ & Y & No \\
\hline \multicolumn{2}{|c|}{ Local Government Reserves } & $\mathrm{N} / \mathrm{A}$ & $x$ & $x$ & Y & No \\
\hline
\end{tabular}

Abbreviations: VCTA (Victorian Conservation Trust Act 1972 (Vic)), CFLA (Conservation, Forests and Lands Act 1987 (Vic)), WA (Wildlife Act 1975 (Vic)), PEA (Planning and Environment Act 1987 (Vic)), FFGA (Flora and Fauna Guarantee Act 1988 (Vic)), EPBCA (Environment Protection and Biodiversity Conservation Act 1999 (Cth)), N/A (Not applicable), $Y=$ meets criteria, $X=$ does not meet criteria, ? = unclear * See Fitzsimons (2006) for further explanation on this assessment and Hardy et al. (2018a,b) for more on this mechanism. 


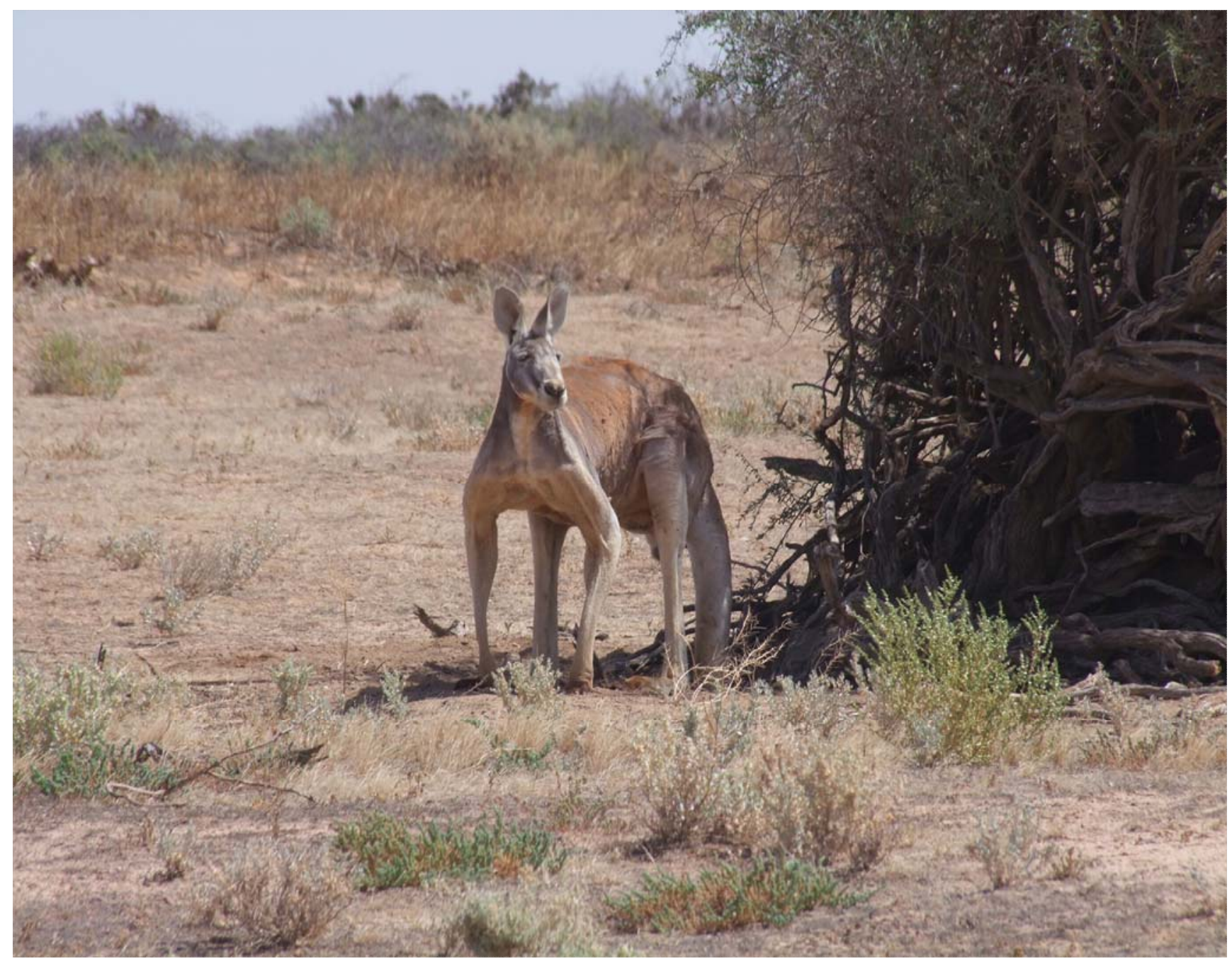

Figure 3. Red Kangaroo on Neds Corner Station, a property purchased by Trust for Nature (Victoria) with funds from the National Reserve System Program and thus a privately protected area @ James Fitzsimons

the conservation covenanting programmes, hence dividing into those that would qualify as PPAs (elaborated in Table 3 in Fitzsimons, 2015) and those that would not (Table 5 in Fitzsimons, 2015). While not qualifying as PPAs, these other conservation covenanting programmes would most likely be OECMs on private land. It is important to note that these other covenant mechanisms are effectively managed in the same way as other conservation covenants (and indeed some may have similar recognition under tax deductions/financial incentives; Smith et al., 2016; Department of the Environment and Energy 2018).

It is recognised that not all properties owned by private conservation trusts would necessarily qualify as PPAs under the current National Reserve System criteria (mainly due to legal protection), however they are managed with this explicit intent and are moving towards greater security and many would be widely considered as 'PPAs' (whether they formally qualified or not).

However, just because a broad 'mechanism' (e.g. conservation covenants) may qualify broadly as a PPA, this does not mean all individual 'agreements' signed as part of that programme would qualify as a PPA. For example, in Queensland, conservation covenants (termed 'Nature Refuges') are generally classified as protected areas, even if they allow activities such as commercial cattle grazing, which ordinarily would not be considered appropriate in a protected area. Taylor (2012) suggests a more flexible approach would see the Nature Refuge internally zoned to define areas primarily for conservation (which would be considered protected areas) and those that allow grazing (which would still be Nature Refuges, but not protected areas). 


\section{South Africa}

South Africa is recognised as one of the world's 17 mega -diverse countries, containing three of the 34 global biodiversity hotspots (Myers et al., 2000). Its diverse ecosystems are vital to the persistence of biodiversity and the functioning of ecological infrastructure essential to the benefit of its people and its economy. The South African Government's National Development Plan 2030 recognises the "need to protect the natural environment in all respects" (Government of South Africa, 2012) and identified protected area expansion as a key tool to achieving this in the National Biodiversity Strategy and Action Plan (Government of South Africa, 2015).

South Africa's protected area, PPA and OECMequivalent policy framework

South Africa has extensive policy and legislative frameworks to address the challenge of expanding the protected area network and has made a clear distinction between protected areas and conservation areas. South Africa defines a protected area as an area of land or sea that is formally protected in terms of the Protected Areas Act (2003) and managed mainly for biodiversity conservation (SANBI, 2016). In contrast, conservation areas are areas of land or sea not formally protected in terms of the Protected Areas Act but nevertheless managed at least partly for biodiversity conservation (SANBI, 2016). Conservation areas are defined according to criteria and attributes that do not constitute long-term security and permanence and thus, in South Africa, do not count towards the protected area estate but contribute towards the wider conservation estate in South Africa. There are a broad range of mostly undefined sub-categories within this catch-all designation, including Biodiversity Partnership Areas which clearly meet the criteria of OECMs. Protected areas and conservation areas are recognised and reported on separately.

South Africa's National Protected Area Expansion Strategy (Government of South Africa, 2010) notes that meeting national policy objectives requires the expansion of protected areas on state, private and communally owned land. This is noted as of particular importance in the face of limited resources, gaps in comprehensive coverage across all biomes, and the reality that approximately 75 per cent of South Africa's land surface is held in one or other form of private ownership. South Africa provides for the declaration of protected areas on state or privately owned land, with the consent of the landowner, with no differentiation in the legal status, rights or responsibilities of the landowner on the basis of ownership. South Africa's protected areas on privately or communally owned land correspond clearly with PPAs and are first and foremost, protected areas. Currently, 35 per cent of the terrestrial protected area estate in South Africa is privately owned and 5 per cent is communally owned, essentially South Africa's recognised PPAs constitute 40 per cent of the entire protected area network (Figure 4).

South Africa's primary tool for the advancement of both the protected area and conservation area estates on privately owned land, is the national biodiversity stewardship initiative. Biodiversity stewardship is an approach to securing land in biodiversity priority areas through entering into agreements with private and communal landowners, led by conservation authorities and supported by conservation NGOs (Cumming et al., 2017). Biodiversity stewardship agreements provide for a hierarchy of agreements from formally declared protected areas, with durations from 30 to 99 years or in perpetuity, to non-binding agreements. Increasing levels of legal protection and permanence correspond with increasing levels of land use management restrictions and increasing landowner benefits and incentives, such as biodiversity tax incentives.

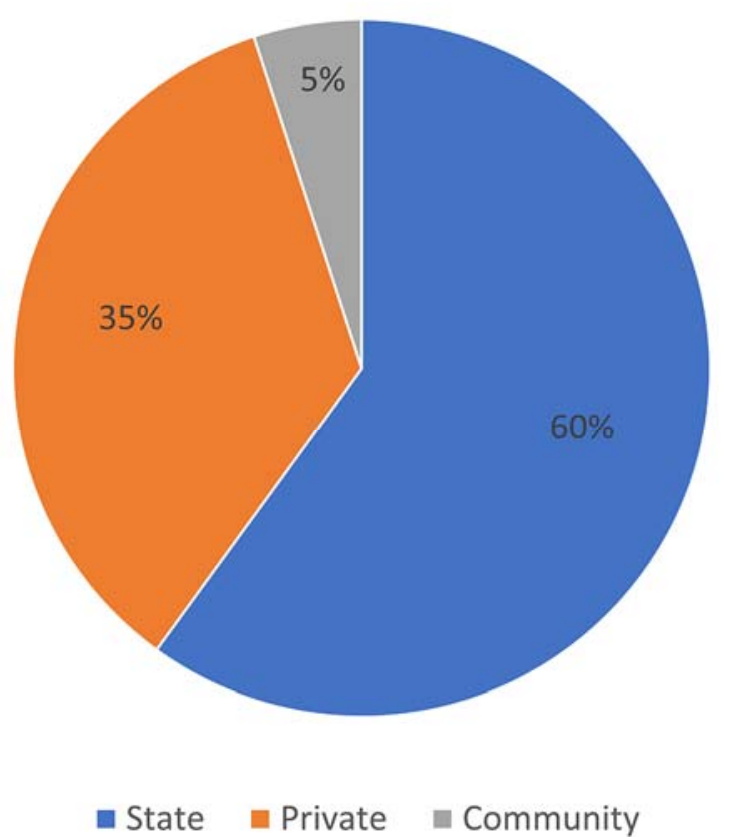

Figure 4. Percentage of ownership of South Africa's terrestrial protected areas. South African PPAs illustrate the key observation that PPAs are PAs in the first instance. Source: Department of Environmental Affairs, 2017. 
The biodiversity stewardship approach in South Africa provides detailed case examples of PPAs and OECMs within its hierarchy of private land conservation agreements and gives a clear indication of the distinction between PPAs and OECMs within the greater context of South Africa's legal and policy frameworks and corresponding tax legislation.

\section{South African PPAs}

South Africa's Protected Areas Act sets out an exhaustive list of protected areas. Biodiversity stewardship utilises three primary types of protected areas, namely: National Parks, Nature Reserves and Protected Environments. All these types are utilised to declare formally recognised protected areas on privately or communally owned land. Such declaration is at the voluntary election of the landowner.

National Parks in South Africa may be state or privately owned. Privately or communally owned national parks (referred to as Contract National Parks within the biodiversity stewardship context), are declared using the same legislation. They are established adjacent to existing state-owned and state-governed National Parks. They are geographic areas with the highest biodiversity value and ecological infrastructure and are formally declared primarily for biodiversity conservation. The declaration term of these agreements ranges up to 99 years or in perpetuity and involves the most stringent management regulations and restrictions, including prohibiting unsustainable land use such as extractive activities. In most instances, landowners of Contract National Parks govern the PPA in a co-management agreement with the state or they may elect to delegate management entirely to the state through the South African National Parks.

Nature Reserves carry the same legal status, duration, biodiversity value, management restrictions and access to incentives as Contract National Parks. Nature Reserves and Contract National Parks are entitled to a biodiversity tax incentive through the Income Tax Act (1962) that recognises a landowner for their commitment to declaring a protected area on private or communal land. Access to this unique tax deduction is only possible through recognition as a PPA. Nature Reserves are generally managed by the landowner and also require a mandatory title deed endorsement through property law, securing the land's protected area status regardless of subsequent changes to land ownership.

Protected Environments are protected areas that can be declared across multiple private properties. This form of
PPA targets somewhat larger areas with biodiversity value and landscape level ecological functioning and due to its slightly flexible nature has somewhat reduced management restrictions, allowing for biodiversity conservation to take place in production landscapes. Protected Environments are declared under national legislation for a minimum of 30 years up to 99 years or in perpetuity. Title deed endorsements are voluntary, but considered to be best practice. Management plans are developed for the area and are implemented by landowners with support from conservation authorities and NGOs.

\section{South African OECMs}

The biodiversity stewardship category of the Biodiversity Partnership Area acts as an umbrella term for what are essentially OECMs. A Biodiversity Partnership Area represents an arrangement that has neither a strong legal or contractual basis nor is it recognised in terms of South African environmental legislation. They contribute to the wider conservation estate but not to the protected area estate as they are not regarded as protected areas. Arrangements with landowners that provide no or limited legal security, little or no permanence, and are managed with only a partial objective of conservation fall within the category of Biodiversity Partnership Area.

Conservancies in South Africa are a definitive example of OECMs. These areas are geographically defined, extending across multiple properties, often comprising a mix of commercial agriculture and natural areas. A short to medium term contract is signed between the participating landowners and the provincial conservation agency regarding environmental management activities on the properties. The degree to which the land is managed for conservation varies widely, and biodiversity conservation is not the primary objective of the land use, as in protected areas. It is more often an ancillary objective, which can be easily set aside when competing economic or other goals take preference, or landowner attitudes towards conservation change. The weaker legal status, lack of long-term conservation intent and the fact that biodiversity conservation is not a primary objective all align these categories with the IUCN guidance regarding OECMs (IUCN WCPA, 2018).

\section{Reporting on PPAs in South Africa}

The South African government documents the declaration of PPAs in determining its progress against both national and international protected area targets and reports all state-owned and privately or communally owned National Parks, Nature Reserves, 
and Protected Environments to the WDPA, recognising that these types of PPAs are essentially protected areas. The Department of Environmental Affairs also centrally keep records of certain categories of conservation areas and has noted a certain incongruity within WDPA records regarding the reporting on protected areas and conservation areas. South Africa makes a clear distinction between the two networks and bases this distinction on the legal certainty and security, permanence and duration, and management objective of each type of agreement. These distinctions align clearly with the IUCN definition of protected areas and privately protected areas and the guidance and recommendations provided thus far on OECMs.

\section{CONCLUSION}

In the case studies illustrated here the fundamental distinction we make between privately protected areas and OECMs is that the governance arrangements or land ownership are a secondary filter, only relevant after first determining whether or not a site qualifies as a protected area as defined by the IUCN (Figure 1, Bingham et al., 2017). Common features of PPAs in the two countries include a high level of legal protection and a primary purpose of biodiversity conservation. OECMs may have one of these but not both (i.e. they may have a high level of protection but biodiversity conservation is ancillary, or biodiversity may be the primary focus but the legal protection mechanism used is weaker and lacks a long-term duration).

It should be recognised that despite the definitions being standardised by IUCN, the term 'privately protected areas' is often used more broadly for private land conservation mechanisms that include a legislative or contractual component (even if not in perpetuity) or generally for land owned by conservation land trusts or similar (Fitzsimons, 2015). Similarly, 'OECM' is not a term used by public or private land conservation practitioners. While definitional work continues, some

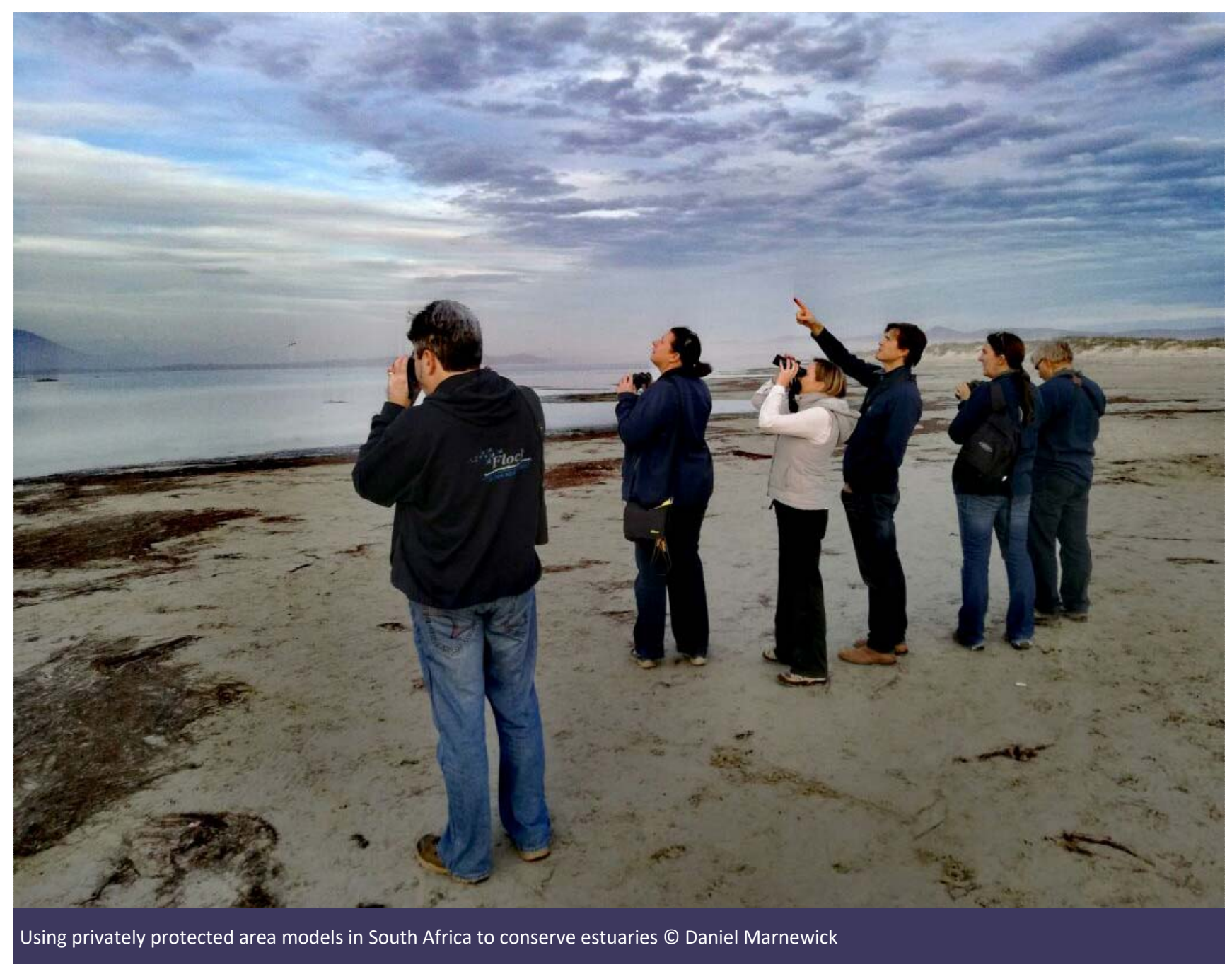




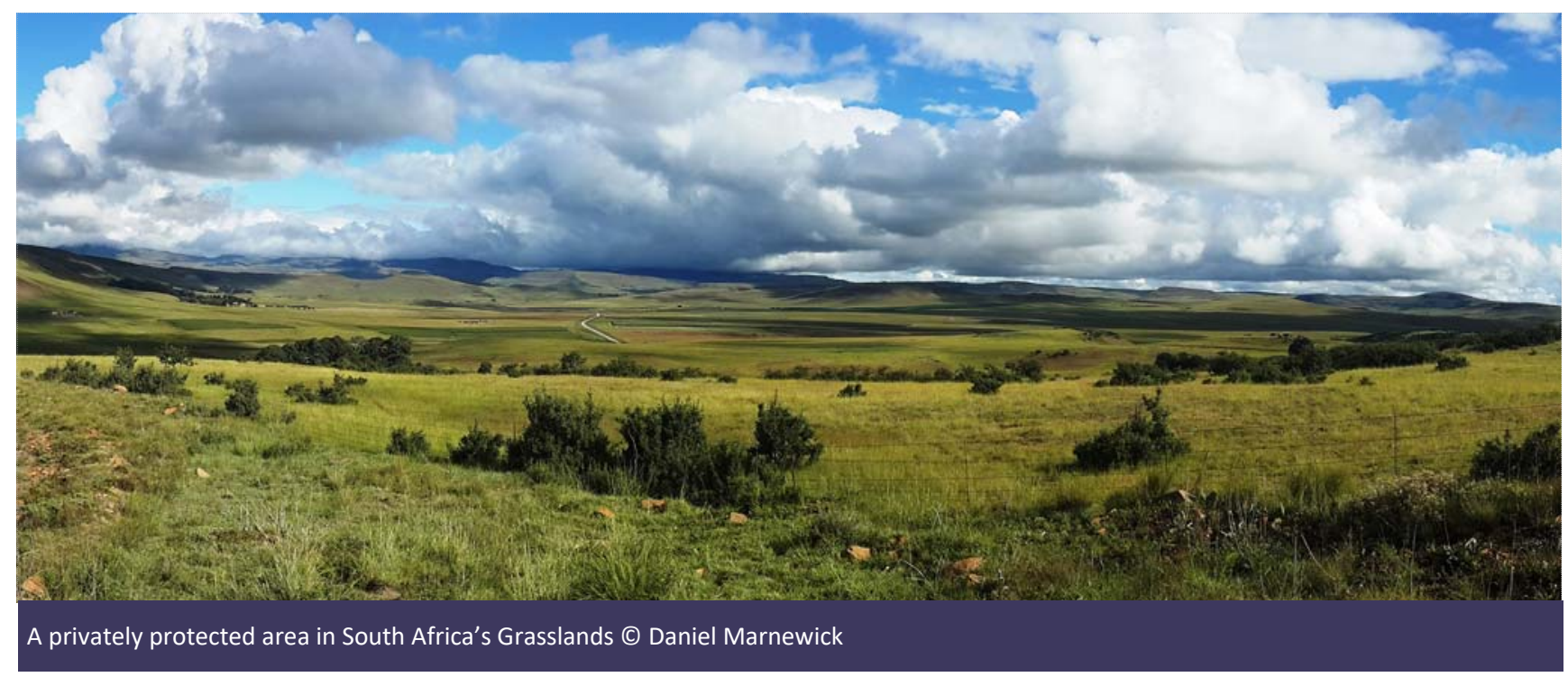

advocate for the use of a more user-friendly term, for example, 'conserved area' (J onas et al., 2017). While clearer language for any classification is to be encouraged, it will be important to avoid creating confusion for practitioners and policy makers by using very similar terms (e.g. 'privately protected area' and 'privately conserved area' - there is likely to be little distinction between the terms 'protected' and 'conserved' for most people). Consultation on suitable terms (beyond the already agreed term OECM) will be important to avoid this confusion, acknowledging the clear acceptance and currency of the term privately protected areas already in existence. As the definition of conserved areas on private land that are not PPAs becomes clearer and formally accepted, it may become easier to grasp the differences between the two. While similar in many respects, the touchstone is the definition of a protected area. Privately protected areas satisfy that definition. Areas that do not may be OECMs on private land.

\section{ABOUT THE AUTHORS}

Brent A. Mitchell is Senior Vice President at the Quebec Labrador Foundation / Atlantic Center for the Environment based in Massachusetts, USA. In his early career he worked as a field biologist for America's oldest land trust, The Trustees of Reservations. Since joining QLF in 1987 he has promoted private approaches to nature stewardship through projects and exchanges in more than 50 countries. Brent chairs the Specialist Group on Privately Protected Areas and Nature Stewardship of IUCN's World Commission on Protected Areas. $\mathrm{He}$ is also a founding partner in the (US) National Park Service's Stewardship Institute.
James A. Fitzsimons is the Director of Conservation for The Nature Conservancy's Australia Program and is an Adjunct Professor at the School of Life and Environmental Sciences, Deakin University. His particular research interests are in the fields of protected area policy, practical conservation planning and mechanisms to integrate conservation outcomes on public and private lands. He has worked in the fields of conservation policy and planning for government environment departments and agencies, and for nongovernment environment organisations.

Candice M.D. Stevens is head of Policy \&Advocacy at BirdLife South Africa and is an environmental tax specialist. Candice is responsible for the introduction of South Africa's first biodiversity tax incentive dedicated to the South African Protected Areas Network. Her work is comprised of advancing and testing innovative biodiversity finance solutions and policy integration relating to protected area expansion on privately and communally owned land. Candice has a background in both law and commerce as well as experience in protected area expansion, biodiversity finance, and environmental law and policy-making on financial incentives.

Dale R. Wright is the Important Bird and Biodiversity Areas (IBA) Conservation Implementation Manager for BirdLife South Africa, based in Cape Town. He has previously spent time managing a protected area in Tanzania and also working in a sustainable agriculture project focused on South Africa's wine industry. His current position focuses on protected area expansion within the South Africa IBA network, primarily utilising privately protected areas and OECMs as the mechanisms for securing critical biodiversity. 


\section{REFERENCES}

Bingham, H., Fitzsimons, J.A., Redford, K.H., Mitchell, B.A., BezauryCreel, J. and Cumming, T.L. (2017). Privately Protected Areas: Advances and challenges in guidance, policy and documentation. PARKS 23 (1): 13-28. doi 10.2305/ IUCN.CH.2017.PARKS-23-1HB.en

Bowles I., Downes D., Clark, D. and Guérin-McManus, M. (1988). Economic incentives and legal tools for private sector conservation. Duke Environmental Law \& Policy Forum 8: 209244.

Cumming, T., Driver, A., Pillay, P., Martindale, G., Purnell, K., McCann and Maree, K. (2017). The business case for biodiversity stewardship. A report produced for the Department of Environmental Affairs. Pretoria: South African National Biodiversity Institute.

Department of the Environment and Energy (2018). Conservation covenants: Approved covenanting programs. Programs approved by the Environment Minister for the purposes of the Income Tax Assessment Act 1997. http:// www.environment.gov.au/biodiversity/conservation/ covenants/approved-programs

Dudley, N. (ed.) (2008). Guidelines for Applying Protected Area Management Categories. Gland, Switzerland: IUCN.

Fitzsimons, J.A. (2006). Private Protected Areas? Assessing the suitability for incorporating conservation agreements over private land into the National Reserve System: A case study of Victoria. Environmental and Planning Law Journal 23: 365-385.

Fitzsimons, J.A. (2015). Private protected areas in Australia: Current status and future directions. Nature Conservation 10: 1-23. doi: 10.3897/natureconservation.10.8739

Government of South Africa (2003). National Environmental Management: Protected Areas Act No. 57 of 2003. Pretoria: Department of Environmental Affairs.

Government of South Africa (2010). National Protected Area Expansion Strategy for South Africa 2008. Priorities for expanding the protected area network for ecological sustainability and climate changes adaptation. Pretoria: Department of Environmental Affairs.

Government of South Africa (1962). Income Tax Act No. 58 of 1962. Pretoria: Ministry of Finance.

Government of South Africa (2015). The National Development Plan. Pretoria: Department: The Presidency.

Government of South Africa (2015). National Biodiversity Strategy and Action Plan. Pretoria: Department of Environmental Affairs.

Hardy M.J., Bekessy S.A., Fitzsimons J.A., Mata L., Cook C., Nankivell A. and Gordon A. (2018a). Protecting nature on private land using revolving funds: Assessing property suitability. Biological Conservation 220: 84-93. doi: 10.1016/j.biocon.2018.01.026

Hardy, M.J., Fitzsimons, J.A., Bekessy, S.A. and Gordon, A. (2018b). Factors influencing property selection for conservation revolving funds. Conservation Biology 32: 276-286. doi: 10.1111/cobi.12991

IUCN WCPA (2018). (Draft) Guidelines for Recognising and Reporting Other Effective Area-based Conservation Measures, Version 1. Gland, Switzerland: IUCN.

Jonas, H.D., Lee, E., Jonas, H.C., Matallana-Tobon, C., Sander Wright, K., Nelson, F. and Enns, E. (2017). Will 'Other Effective Areabased Conservation Measures' increase recognition and support for ICCAs? PARKS 23 (2): 63-78. doi: 10.2305/ IUCN.CH.2017.PARKS-23-2HDJ.en

Mitchell, B.A. (2005). Editorial. PARKS 15 (2): 1-5.

Myers, N., Mittermeier, R.A, Mittermeier, C.G., da Fonesca, G.A.B. and Kent, J. (2000). Biodiversity hotspots for conservation priorities. Nature 403: 853-858. doi:10.1038/35002501.

NRMMC (2005). Directions for the National Reserve System: A partnership approach. Canberra: Natural Resource Management Ministerial Council.

NRMMC (2009). Australia's Strategy for the National Reserve System 2009-2030. Canberra: Natural Resource Management Ministerial Council.

Smith, F., Smillie, K., Fitzsimons, J., Lindsay, B., Wells, G., Marles, V., Hutchinson, J., O'Hara, B., Perrigo, T. and Atkinson, I. (2016). Reforms required to the Australian tax system to improve biodiversity conservation on private land. Environmental and Planning Law Journal 33: 443-450. doi: 10536/DRO/ DU:30087854

South African National Biodiversity Institute (SANBI) (2016). Lexicon of Biodiversity Planning in South Africa. Beta Version, June 2016. Pretoria: South African National Biodiversity Institute.

Stolton, S., Redford, K.H. and Dudley, N. (2014). The Futures of Privately Protected Areas. Gland, Switzerland: IUCN.

Taylor, M. (2012). Getting results in conservation. In: P. Figgis, J. Fitzsimons and J. Irving (eds.), Innovation for 21st Century Conservation, pp. 66-71. Sydney: Australian Committee for IUCN.

Taylor, M., Fitzsimons, J. and Sattler, P. (2014). Building Nature's Safety Net 2014: A decade of protected area achievements in Australia. Sydney: WWF-Australia.

WCPA ANZR (2000). Application of IUCN Protected Area Management Categories: Draft Australian Handbook. Australia: World Commission on Protected Areas Australia and New Zealand Region. 


\section{RESUMEN}

La conservación de tierras privadas ejerce un papel cada vez más importante para garantizar que las redes mundiales de conservación sean integrales, adecuadas y representativas. Para contribuir a la Meta 11 de Aichi del Convenio sobre la Diversidad Biológica, las áreas en tierras privadas deben ser áreas bajo protección privada (APP) u "otras medidas de conservación eficaces basadas en áreas" (OECM, por sus siglas en inglés) en tierras privadas. Hacemos una comparación entre las APP y las OECM en tierras privadas, aclaramos los conceptos erróneos y presentamos estudios de caso que ilustran cómo dos jurisdicciones, Australia y Sudáfrica, han trabajado aplicando estas categorías a los mecanismos locales de conservación de tierras privadas.

\section{RÉSUMÉ}

La conservation des terres privées joue un rôle de plus en plus important pour assurer que les réseaux mondiaux de conservation soient complets, pertinents et représentatifs. Pour contribuer à atteindre l'Objectif 11 d'Aichi établi à la Convention sur la Diversité Biologique, les aires situées sur des terres privées doivent soit constituer des aires protégées à gouvernance privée (APP), soit bénéficier d'autres mesures de conservation efficaces par zone (OECM). Dans ce rapport nous comparons les APP aux OECM en place sur des terres privées, proposons de clarifier les idées reçues et de fournir des cas pratiques sur la façon dont deux gouvernements, l'Australie et l'Afrique du Sud, ont appliqué ces catégories aux systèmes locaux de conservation sur les terres privées. 